\title{
緑内障における網膜循環障害機序の解明と新規緑内障治療薬の探索
}

\author{
森 麻美, ${ }^{*, a}$ 中原 努, ${ }^{a}$ 倉内祐樹, ${ }^{b}$ 坂本謙司, ${ }^{a}$ 石井邦雄 ${ }^{a}$
}

\section{Elucidation of Dysfunctional Mechanisms of Retinal Circulation in the Rat Models of Glaucoma and Exploration of Novel Therapeutic Drugs}

\author{
Asami Mori, ${ }^{*, a}$ Tsutomu Nakahara, ${ }^{a}$ Yuki Kurauchi, ${ }^{b}$ \\ Kenji Sakamoto, ${ }^{a}$ and Kunio Ishii ${ }^{a}$ \\ ${ }^{a}$ Department of Molecular Pharmacology, Kitasato University School of Pharmaceutical Sciences; \\ 5-9-1 Shirokane, Minato-ku, Tokyo 108-8641, Japan: and ' Program for Leading Graduate \\ Schools, Kumamoto University; 5-1 Oe-honmachi, Chuo-ku, Kumamoto 862-0973, Japan.
}

(Received August 27, 2013)

\begin{abstract}
In recent times, glaucoma has become the leading cause of acquired blindness among the Japanese. As visual disorders markedly decrease the quality of life (QOL), it is important to develop new strategies for preventing the onset of and delaying the progression of glaucoma. Glaucoma has long since been recognized as a serious disease caused by increased intraocular pressure and subsequent injury and death of the neuronal retinal cells. Therefore, numerous studies have focused on the mechanisms that damage neuronal cells and on the drugs that possess protective effects in reversing this damage. However, injury to the retinal vasculature has been recently shown in animal models of glaucoma. Hence, thus far, only few papers have been published on retinal circulation in glaucoma. These study results have indicated that retinal circulation is altered in glaucoma and that this vascular abnormality may be the cause of and/or may accelerate retinal degeneration. In this report, we have attempted to elucidate the mechanisms of retinal circulation and explore novel drugs for the treatment of retinal circulation disorders. We have also introduced here our previous research results on retinal circulation. We reported that the drugs that improved retinal circulation, by intravitreal injection, in the rat model of glaucoma also inhibited retinal nerve injury, thereby representing possibilities that they might be novel candidate drugs for glaucoma prevention and treatment.
\end{abstract}

Key words_-glaucoma; retinal circulation; prostanoid EP2 receptor agonist; $\beta_{3}$ adrenoceptor agonist; $N$-methyl-Daspartate

\section{1. はじめに}

網膜は 10 層からなる神経細胞が層構造を形成し ており，外部から与えられた光情報を受容・変換 し，神経のインパルスとして脳に伝えるという重要 な役割を演じている，網膜内層（内境界膜，神経線 維層, 神経節細胞層，内網状層，内顆粒層，外網状 層）は網膜循環により，また網膜外層（外顆粒層， 外境界膜, 桿体錐体層, 網膜色素上皮細胞層) は脈 絡膜循環により栄養されているが, 1 ) 網膜血管に

The authors declare no conflict of interest.

$a$ 北里大学薬学部分子薬理学教室 $(=108-8641$ 東京都 港区白金 5-9-1), b熊本大学大学院先導機構博士課程 教育リーティングプログラム（テ862-0973 熊本市中央 区大江本町 5-1)

*e-mail: moria@pharm.kitasato-u.ac.jp

本総説は, 日本薬学会第 133 年会シンポジウム S30-

201 で発表した内容を中心に記述したものである。
は，血液網膜柵という水溶性物質の透過に対するバ リアー機構2)や血流の自動調節能が存在する3)な ぞ，脳血管との間に多くの類似性が見い出されてお

り，網膜血管は中枢血管に分類されている. 網膜は単位組織重量当たりの酸素要求量が非常に 多いことから, 1,2) 網膜循環障害による網膜虚血は, 網膜神経障害の原因となり得る。実際，わが国にお ける後天性失明原因の第一位である緑内障も, 網膜 循環障害が原因で起こることが報告されている. ${ }^{4,5)}$ ヒトは外からの情報の 8 割以上を視覚から取得して いるため, 視機能の低下をもたらす種々の眼疾患 は，死に至るような疾病ではないものの，著しい quality of life（QOL）の低下をもたらす。したが つて, 緑内障の発症及び進行を抑制することは, 医 学・薬学研究者に与えられた重要な課題である.

これまで緑内障は, 主として眼圧の上昇によって 
網膜神経細胞死が生じ，視覚障害をもたらす疾患と 捉えられてきた。 そのため, 緑内障の研究は網膜神 経細胞死のメカニズムや神経保護薬の探索に関する ものがほとんどである。緑内障の治療には眼圧下降 薬が用いられるが，わが国の緑内障の約 7 割が眼圧 上昇を伴わない正常眼圧緑内障であるのが現状であ る. 正常眼圧緑内障における視神経障害機序として 網膜循環障害の関与が注目されつつあるが，網膜血 流障害に着目した報告は少ない

しかし最近では，緑内障モデル動物において網膜 微小血管障害の存在が報告されてきている. ${ }^{6-8)}$ そ れによって生じる網膜血流障害が，網膜神経細胞死 をさらに加速させる可能性が考えられるため，われ われは緑内障の新たな治療戦略として, 網膜循環改 善作用を有する薬物に着目して研究を進めている.

網膜循環に関する in vivo 研究の多くは，ウシ， ブタ，サル，ネコ，ウサギなどの中・大型動物を用
いて，臨床で用いられている機器によりなされてき た. しかし種々の病態モデルや遺伝子改変モデルが 確立されているラット，マウスなどに臨床機器を用 いることは困難であり，小動物を用いた in vivo 研 究は非常に少ないというのが現状である。そこでわ れわれは，独自に小動物用眼底撮影装置を製作し， in vivo でラット網膜血管の反応性を評価できるシ ステムを構築することにより，正常9-15) 及び病態 (糖尿病, 高血圧，緑内障）モデルラット16-22) にお ける網膜循環に関する一連の研究を行ってきた。本 稿では，われわれがこれまでに行ってきた一連の網 膜循環調節機構についての研究成果と，これまでに 検討してきた 46 種類の血管拡張薬（Fig. 1)の中か ら, 網膜循環改善薬の候補として挙げることができ る薬物について紹介する，さらに，網膜循環と神経 機能との関連にも言及することにより，今後の緑内 障治療戦略について論じてみたい.

\begin{tabular}{|c|}
\hline 【Ca ${ }^{2+}$ channel inhibitor】 \\
Nicardipine \\
Nifedipine \\
Flunarizine \\
Amlodipine \\
Cilnidipine \\
\hline \hline$\alpha_{1}$ adrenoceptor antagonist \\
Bunazosin \\
$<\alpha_{1 \mathrm{~A}}$ adrenoceptor antagonist $>$ \\
RS100329 \\
$<\alpha_{1 \mathrm{~B}}$ adrenoceptor antagonist $>$ \\
$\mathrm{L-765314}$ \\
$<\alpha_{1 \mathrm{D}}$ adrenoceptor antagonist $>$ \\
BMY 7378 \\
\hline \hline
\end{tabular}

【 $\beta$ adrenoceptor agonist】 Adrenaline Isoprenaline $<\beta_{2}$ adrenoceptor agonist $>$ Salbutamol Formoterol $<\beta_{3}$ adrenoceptor agonist $>$ BRL37344 CL316243

\section{【cAMP/cGMP increasing drugs】}

[Adenylyl cyclase activator] [Phosphodiesterase inhibitor]

Forskolin Theophylline

Colforsin

\section{[Vasodilatory prostaglandin] (IP receptor agonist) Prostacyclin Beraprost}

\section{(EP receptor agonist)} Prostaglandin $\mathrm{E}_{2}$ Prostaglandin $\mathrm{E}_{1}$ Lipo-prostaglandin $E_{1}$ <EP2 receptor agonist> ONO-AE1-259-01 <EP4 receptor agonist> ONO-AE1-329

\section{[Neoropeptide]} Adrenomedullin Urocortin Urocortin 2

\section{【EC dependent vasodilator】 Acetylcholine Bradykinin Adenosine}

<Phosphodiesterase 4 inhibitor> Rolipram

Ro-20-1724

YM-976

\section{[Cyclic nucleotide analog]} 8-cpt-cAMP 8-cpt-cGMP

[NO donner]

Sodium nitroprusside NOR3

L-Citrulline

\begin{tabular}{|c|}
\hline 【K $\mathrm{K}_{\mathrm{ATP}} / \mathrm{BK}_{\mathrm{Ca}}$ channel opener】 \\
Pinacidil \\
Nicorandil \\
BMS-191011 \\
\hline $\begin{array}{c}\text { 【Others】 } \\
\text { Ibudilast Fasudil } \\
\text { Vinpocetin Hydralazine }\end{array}$ \\
\hline
\end{tabular}

Fig. 1. Forty-six Kinds of Vasodilation Drugs Used in Our Previous Studies 


\section{2. 一酸化窒素による網膜循環調節機構}

血管内皮細胞は，血管緊張度の調節に需要な役割 を担っている種々の物質を産生する。そのうちの 1 つである一酸化窒素（NO）は，網膜血管床におい ても血流量増大作用を示すことが報告されてい る. ${ }^{23)} \mathrm{NO}$ は血管平滑筋細胞の可溶性グアニル酸シ クラーゼ (soluble guanylyl cyclase; sGC) を活性化 し，細胞内 cGMP 量を増加させることにより強力 な血管拡張作用を示すことが広く知られている. ${ }^{24)}$ しかし，大変興味深いことに，摘出ブタ網膜血管を 用いた研究では，NO がプロスタサイクリン $\left(\mathrm{PGI}_{2}\right)$ の産生・遊離増大を介して血管を拡張させることが

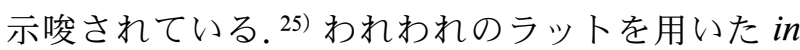
vivo 実験においても，NO 供与体である NOR3 の 作用は，sGC 阻害薬である ODQ では影響を受けな かったが，アデニル酸シクラーゼ（adenylyl cyclase；AC）阻害薬である SQ 22536 で有意な抑制が 観察された。 ${ }^{10,11)}$ この NOR3 による網膜血管拡張反 応に対して, 選択的 cycloxygenase (COX) -2 阻害 薬の nimesulide 及び NS-398 は影響を及ぼさなかっ たが，非選択的 COX 阻害薬の incomethacin と選 択的 COX-1 阻害薬の SC-560 は有意な抑制効果を 示した。 また，ラット網膜血管では sGC の発現が非 常に少ないこと，さらにCOX-2 ではなく, COX-1

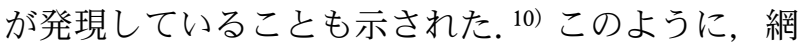
膜血管ではsGCがほとんど発現していないことか ら，NO は細胞内 cGMP の増大ではなく，アラキ
ドン酸カスケードに作用し，COX-1 の活性化に由 来する prostanoid(s) の産生を介して， cAMP を増 大させることで血管を拡張させることが示唆された (Fig. 2).

以上の結果より， cAMP シグナル経路が網膜循 環の調節において重要な役割を演じていることが明 らかになり, 細胞内 cAMP を増加させる薬物は網 膜循環改善薬の候補となり得ると考えられた。そこ でわれわれは，自律神経反射を抑制した tetrodotoxin 処置ラットに各種 cAMP 増加薬を静脈内投与 し，それによって生じる血圧，心拍数及び網膜血管 径の変化を指標として，全身性の作用と網膜血管に 対する作用を比較し，網膜血管に選択的に作用する 薬物の探索を行っている.

\section{3. 網膜血管に対するプロスタノイド EP2 受容} 体刺激薬と $\mathbf{P G I} \mathbf{2}_{\mathbf{2}}$ の作用

cAMP 増加薬は, 全身の血管及び心臓に作用し, 血圧低下や心悸六進をもたらす。しかし， $\mathrm{PGE}_{2}$ や $\mathrm{PGI}_{2}$ など血管拡張性 prostanoid (s) は，心臟に対 する作用がないことが報告されている. ${ }^{26)}$ 内因性 prostanoid (s) は，NO とともに血管内皮細胞で産 生され，網膜や脈絡膜などの眼循環調節に重要な役 割を果たしているとの多くの報告がある. ${ }^{27-31)} \mathrm{PGE}_{2}$ の受容体には, prostanoid EP1-4 の 4 つのサブタ イプが存在するが，EP2 及び EP4 受容体が cAMP を増大させる Gs タンパク質共役型のサブタイプで あり，また $\mathrm{PGI}_{2}$ が作用する IP 受容体も同様のメ

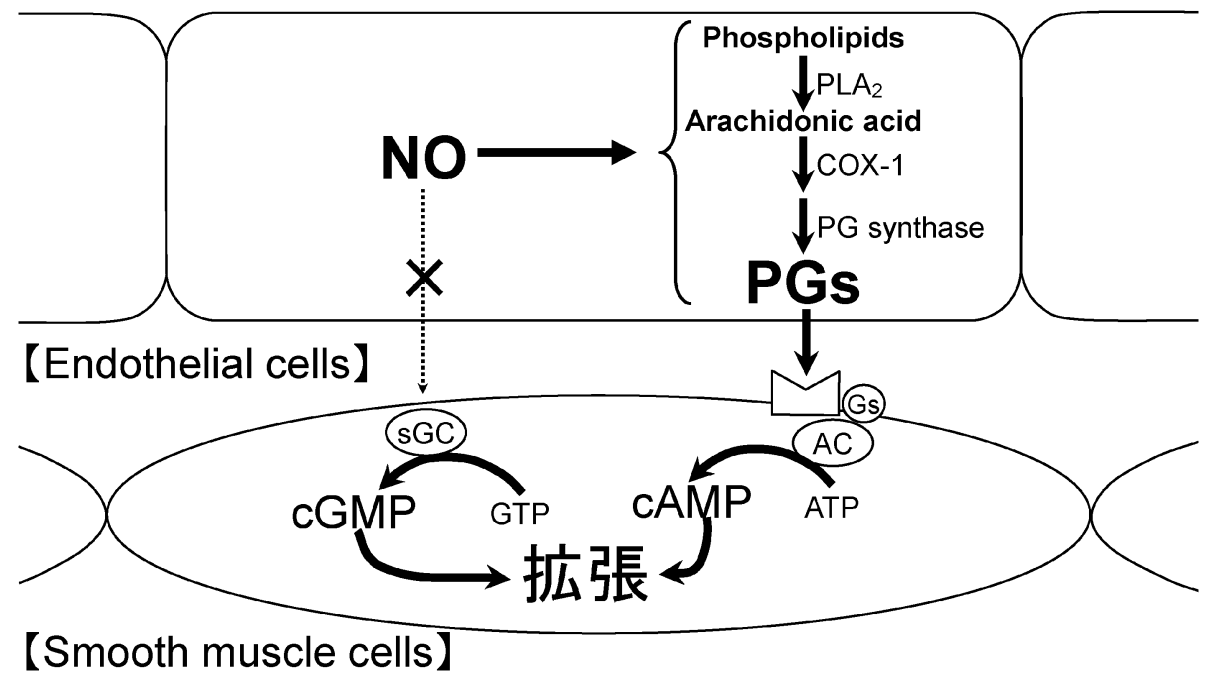

Fig. 2. Vasodilatory Mechanisms of Nitric Oxide (NO) in the Retinal Vasculature

$\mathrm{AC}$; adenylyl cyclase, COX; cyclooxygenase, $\mathrm{NO}$; nitric oxide, $\mathrm{PG}$; prostaglandin, $\mathrm{PLA}_{2}$; phospholipase $\mathrm{A}_{2}$, sGC; soluble guanylyl cyclase. 
カニズムで機能している. ${ }^{32-34)}$ そこで，ラットにお ける in vivo 実験において EP2, EP4 及び IP 受容体 刺激薬の作用を検討したところ，EP2 受容体刺激 薬である ONO-AE1-259-01 と IP 受容体を刺激する $\mathrm{PGI}_{2}$ は，いずれも血圧低下が観察されるよりも低 用量から網膜血管拡張作用を示すこと，また心拍数 には影響を及ぼさないということが明らかとなつ た. ${ }^{14,15)}$ このように, $\mathrm{EP} 2$ 受容体刺激薬及び $\mathrm{PGI}_{2}$ は，末梢血管よりも網膜血管により強く作用し，心 臓に対する直接作用が弱いことから，網膜循環改善 薬の候補となり得ることが示された.

4. 網膜血管に対する $\beta_{2}$ アドレナリン受容体刺 激薬と $\beta_{3}$ アドレナリン受容体刺激薬の作用

循環カテコラミンは, 血管緊張性を収縮性あるい は拡張性に調節する重要な因子である。そこで, adrenaline 及び noradrenaline の作用について検討 したところ，いずれも血圧を用量依存的に上昇させ たものの，網膜血管に対する作用は異なり，adrenaline は網膜血管を拡張させるが， noradrenaline は 網膜血管を収縮させるという結果が得られた. ${ }^{35)} こ$ の adrenaline による網膜血管拡張反応は, $\beta_{1} / \beta_{2}$ ア ドレナリン受容体遮断薬である propranolol 及び $\beta_{3}$ アドレナリン受容体遮断薬である L-748337 によっ て収縮に転じた。また， adrenalineによる昇圧反応 は propranolol によってさらに増強したものの, L-748337 による影響は受けなかった。これらの結 果は, adrenaline の $\beta$ アドレナリン受容体を介した 拡張作用は $\alpha_{1}$ アドレナリン受容体を介した収縮作 用よりも強いこと，そして adrenaline による網膜 血管拡張反応には， $\beta_{1} / \beta_{2}$ アドレナリン受容体のみ ならず， $\beta_{3}$ アドレナリン受容体も関与しているこ とが明らかとなった. ${ }^{35)}$ 一方, noradrenalineによる 網膜血管及び末梢血管収縮反応は，propranolol 及 び L-748337 の影響を受けなかった。この noradrenaline による血管収縮反応についてさらに検討 したところ, noradrenaline による網膜血管収縮反 応及び昇圧反応は， $\alpha_{1 \mathrm{~B}}$ アドレナリン受容体ではな く， $\alpha_{1 \mathrm{~A}}$ 及び $\alpha_{1 \mathrm{D}}$ アドレナリン受容体を介している ことも示された. ${ }^{36)}$ 以上のことから, 網膜血管拡張 反応に $\beta_{1} / \beta_{2}$ 及び $\beta_{3}$ アドレナリン受容体が関与し ていることが明らかになつたため，各種 $\beta$ 受容体 刺激薬による反応について検討した.

$\beta_{2}$ アドレナリン受容体刺激薬である salbutamol
を静脈内投与すると，網膜血管は著しく拡張するも のの，同時に著しい血圧の低下と高用量における心 拍数の増大が観察された。一方， $\beta_{3}$ アドレナリン 受容体刺激薬である CL316243 及び BRL37344 の静 脈内投与は，網膜血管を著しく拡張させたが，salbutamol と比較して血圧低下作用は弱く，心拍数を 変化させないことが明らかになった。 ${ }^{37)}$ 以上のこと から， $\beta_{2}$ アドレナリン受容体刺激薬よりも $\beta_{3}$ アド レナリン受容体刺激薬の方が，全身循環に及ぼす影 響が少ない網膜循環改善薬となる可能性が示唆され た.

\section{5. 緑内障と網膜循環について}

緑内障は，なんらかの原因により視神経が障害さ れて萎縮し，視神経乳頭の陥凹や視野狭窄を生じる 疾患である，進行性の網膜神経障害及び視覚障害を 伴うものの, 自覚症状が少ないため, 気付かないう ちに症状が進行し, 治療が遅れて失明に至ることが ある。

グルタミン酸は中枢神経系の興奮性神経伝達物質 であるが，緑内障では過利な細胞外グルタミン酸が $N$-methyl-D-aspartate（NMDA）型受容体を刺激す ることで，網膜神経細胞死に関与していることが広 く知られている. ${ }^{38-40)}$ また, 網膜神経細胞死の原因 として, 神経栄養因子の枯渇, グリアの活性化，興 奮毒性，虚血，酸化ストレスなど，様々な傷害機序 が挙げられるが，いずれの場合も最終的にはアポ トーシスを引き起こすとされる. ${ }^{41-44)}$

このように, 現在の緑内障に関する研究は, 網膜 神経細胞死の機序や網膜神経保護作用に関するもの が主流であり，網膜血流障害に着目した報告は少な い. しかし最近では，緑内障モデル動物において， 網膜微小血管障害が生じることが報告されてい る. ${ }^{6-8)} こ れ ら の$ 結果は, 網膜血管障害による循環 障害が緑内障の原因となつたり，また病態の進行を 加速したりする可能性を示唆している.したがつ て, 網膜循環改善作用を有する薬物が, 新しい緑内 障の予防・治療薬となる可能性が考えられたので, われわれは，これまでに明らかにしてきた網膜循環 改善薬の候補薬物が, 緑内障モデル動物の網膜神経 傷害に対して保護作用を示すか否かについて検討す ることとした。 
6. 緑内障モデルラットの網膜神経傷害に及ばす 網膜循環改善薬の影響

6-1. プロスタノイド EP2 受容体刺激薬プロ スタノイド EP2 受容体刺激薬である ONO-AE1259-01の静脈内投与は網膜血管を強く拡張させる ことを示されたが，同時に降圧反応も観察されたた め, 副作用の軽減を目的として, 同薬物を硝子体内 投与することで検討した。まず，健常ラットに ONO-AE1-259-01（20 pmol/eye）を硝子体内投与 したときの網膜血管の変化を観察したところ，静脈 内投与の場合と同様に，矢印で示す網膜細動脈径に 17.8\%の増大が認められた [Figs. 3(A) and (B)]. そこで次に，実験的緑内障モデルとして汎用されて いる NMDA 硝子体内投与モデルラットで観察され る網膜神経傷害に対し，ONO-AE1-259-01 の同時 投与がぞのような影響を及ぼすかについて検討し た。その結果，ONO-AE1-259-01 は NMDA（200
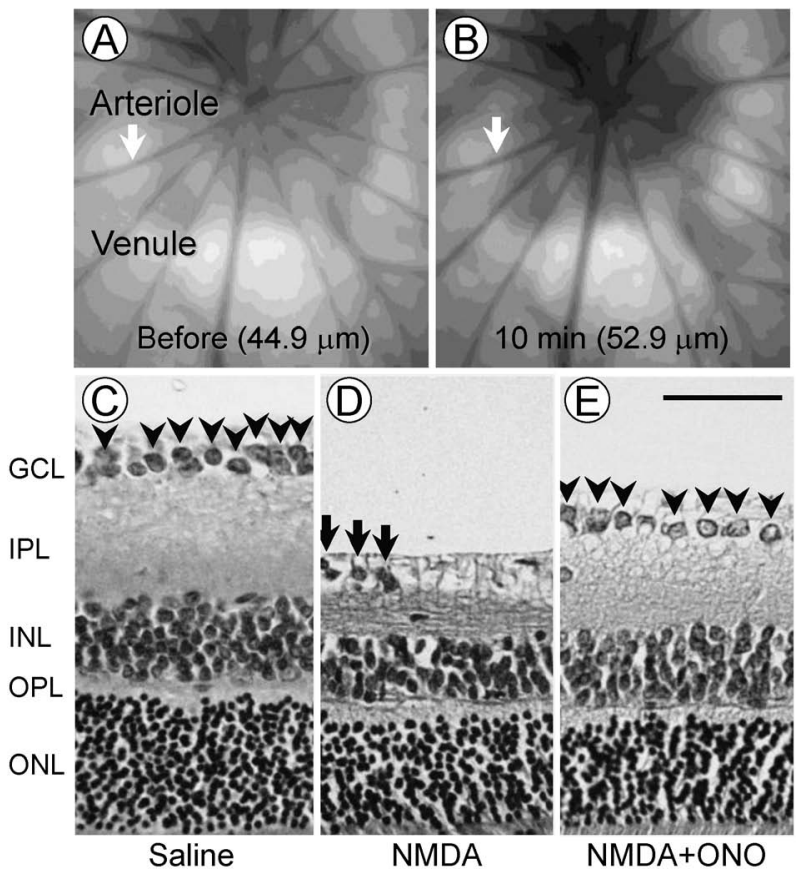

Fig. 3. Effects of Intravitreal Injection of ONO-AE1-259-01 against Retinal Vasculature and Retinal Damage 7 Days after Intravitreal Injection of $N$-methyl-D-aspartate (NMDA)

The diameter of retinal arterioles indicated by white arrows by $17.8 \%$ on 10 min after intravitreal injection of ONO-AE1-259-01 (an EP2 receptor agonist, $20 \mathrm{pmol} / \mathrm{eye}$ ) (A, B). Intravitreal injection of NMDA $(200 \mathrm{nmol} /$ eye) reduced retinal ganglion cells (shown by black arrowheads) and increased pyknosis cells (shown by black arrow) in the ganglion cell layer (GCL) and decreased the thickness of the inner plexiform layer (IPL) (D). ONO-AE1-259-01 (ONO, $20 \mathrm{pmol} / \mathrm{eye}$ ) attenuated the NMDA-induced injuries (E). The thickness of the inner nuclear layer (INL), the outer plexiform layer $(\mathrm{OPL})$, or the outer nuclear layer $(\mathrm{ONL})$ was not changed by NMDA. Scale bar $=50 \mu \mathrm{m}$. $\mathrm{nmol} /$ eye）硝子体内投与による神経節細胞の脱落 と内網状層の層厚減少を有意に抑制することが示さ れた $\left[\right.$ Figs. 3(C)-(E) ]. ${ }^{45)}$ したがって，EP2 受容 体刺激薬は，網膜循環改善作用のみならず，網膜神 経保護作用も示すことから，網膜血流量改善と神経 保護作用を併せ持つ，緑内障治療薬となり得ること が示唆された。

6-2. $\beta_{3}$ アドレナリン受容体刺激薬健常ラッ トの硝子体内に $\beta_{3}$ アドレナリン受容体刺激薬の CL316243（50 nmol/eye）を投与したところ，投与 20 分後には矢印で示す網膜細動脈の血管径が 21.9 \%増大し，その作用は少なくとも投与 60 分後まで 持続していた (Fig. 4). CL316243 の静脈内投与で は弱いながらも降圧反応が観察されていたが, ${ }^{37)}$ 硝 子体内投与では降圧反応は観察されなかった。そこ で次に，NMDA 硝子体内投与によって誘発される 網膜神経傷害に及ぼす CL316243 の影響を検討した ところ，興味深いことに，CL316243 NMDA と 同時に投与しても網膜神経傷害は抑制されないが, NMDA 投与 15 分以降に CL316243 を投与すると, 神経傷害が有意に抑制されるという結果が得られ た。この効果は， $\beta_{3}$ アドレナリン受容体遮断薬に よってほぼ完全に抑制された. ${ }^{46)}$ これらの結果から, CL316243 は $\beta_{3}$ アドレナリン受容体刺激によって NMDA 誘導の網膜神経傷害に対して保護作用を示 すことが明らかになった。したがって， $\beta_{3}$ アドレ ナリン受容体刺激薬も, 網膜血流量改善作用と神経 保護作用を併せ持つ，緑内障治療薬の候補となるか もしれない.

\section{7. おわりに}

本稿では, 網膜循環調節機構における NOの作用 機序として, 通常の血管床とは異なるアラキドン酸 カスケードの活性化による cAMP 産生増大という 経路が存在すること，また cAMP を増大させる薬 物のうち，プロスタノイド EP2 受容体刺激薬及び $\beta_{3}$ アドレナリン受容体刺激薬が，全身循環に及ぼ す影響の少ない網膜循環改善作用を有することを示 した。ささら，緑内障では網膜循環障害が生じる可 能性があり, 網膜血流の低下によって網膜神経に十 分な酸素や栄養を供給できず，網膜神経傷害をさら に悪化させる要因となり得ることを考察した。しか し, EP2 受容体刺激薬や $\beta_{3}$ アドレナリン受容体刺 激薬のような網膜循環改善作用と網膜神経保護作用 


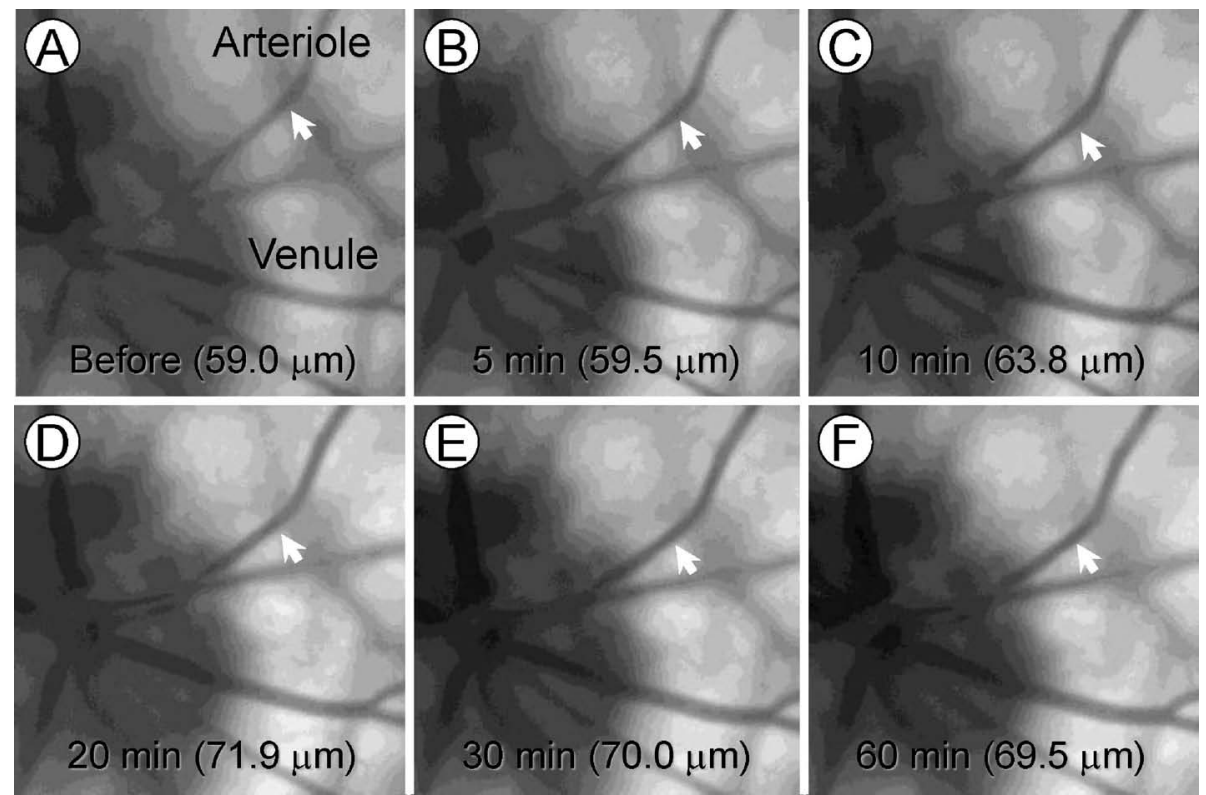

Fig. 4. Effects of Intravitreal Injection of CL316243 against Retinal Blood Vessels

Intravitreal injection of CL316243 (a $\beta_{3}$ adrenoceptor agonist, $50 \mathrm{nmol} / \mathrm{eye}$ ) dilated the retinal vasculature. For example, the retinal arteriolar diameter measured before and 5, 10, 20, 30, and $60 \mathrm{~min}$ after CL316243 injection were 59.0, 59.5, 63.8, 71.9, 70.0, and 69.5 $\mu \mathrm{m}$, respectively (shown by arrows) (A-F) .

を併せ持つ薬物によって，このような悪循環を阻止 することが可能となるかもしれない。これらの薬物 は，現在，眼圧降下薬しか存在しない緑内障に対す る，全く新しい治療薬となり得る。今後，これら薬 物の臨床応用を目標とした研究が進み，緑内障を始 めとする視覚障害を伴う疾患への適応を取得できる ことに期待したい.

謝辞＼cjkstart本研究及び本総説の執筆にあたり，多大 なるご指導，ご鞭撻を賜りました北里大学薬学部分 子薬理学教室 石井邦雄教授に慎んで感謝の意を表 しますとともに，厚く御礼申し上げます。また，研 究の遂行にあたり，多くのご指導，ご協力を頂きま した北里大学薬学部分子薬理学教室の共同研究者及 び教室員の皆様に深く感謝いたします。今回紹介い たしました研究の一部は, 北里大学学術奨励研究資 金（A. M）及び科学研究費補助金（No. 22790260, 24790241 to A. M., No. 10672051, 12672116, 21590102 to K. I.）の補助によって実施されたものであり, ここの深甚なる謝意を表します。

\section{REFERENCES}

1) Whikehart D. R., "Biochemistry of the Eye," 2nd ed., Butterworth-Heinemann, Boston,
2004, pp. 85-132.

2) Bill A., Physiol. Rev., 55, 383-417 (1975).

3) Robinson F., Riva C. E., Grunwald J. E., Pertig B. L., Sinclair S. H., Invest. Opthalmol. Vis. Sci., 27, 1706-1712 (1986).

4) Flammer J., Orgul S., Costa V. P., Orzalesi N., Krieglstein G. K., Serra L. M., Renard J. P., Stefansson E., Prog. Retin. Eye Res., 21, 359-393 (2002).

5) Grieshaber M. C., Flammer J., Curr. Opin. Ophthalmol., 16, 79-83 (2005).

6) Zheng L., Gong B., Hatala D. A., Kern T. S., Invest. Opthalmol. Vis. Sci., 48, 361-367 (2007).

7) Al-Gayyar M. M., Abdelsaid M. A., Matragoon S., Pillai B. A., El-Remessy A. B., Am. J. Pathol., 177, 1187-1197 (2010).

8) Ueda K., Nakahara T., Hoshino M., Mori A., Sakamoto K., Ishii K., Neurosci. Lett., 485, 55-59 (2010).

9) Noguchi M., Mori A., Sakamoto K., Nakahara T., Ishii K., Biol. Pharm. Bull., 32, 19241927 (2009).

10) Ogawa N., Mori A., Hasebe M., Hoshino M., Saito M., Sakamoto K., Nakahara T., Ishii K., Am. J. Physiol. Regul. Integr. Comp. Physiol., 297, R968-R977 (2009). 
11) Ogawa N., Saito M., Mori A., Sakamoto K., Kametaka S., Nakahara T., Ishii K., Naunyn Scgmiedebergs Arch. Pharmacol., 375, 323328 (2007).

12) Kojima N., Saito M., Mori A., Sakamoto K., Nakahara T., Ishii K., Vascular Pharmacol., 51, 119-124 (2009).

13) Miwa T., Mori A., Nakahara T., Ishii K., Eur. J. Pharmacol., 602, 112-116 (2009).

14) Mori A., Saito M., Sakamoto K., Narita M., Nakahara T., Ishii K., Eur. J. Pharmacol., 570, 135-141 (2007).

15) Mori A., Saito M., Sakamoto K., Nakahara T., Ishii K., J. Pharmacol. Sci., 103, 103-112 (2007).

16) Mori A., Saigo O., Hanada M., Nakahara T., Ishii K., J. Pharmacol. Sci., 110, 160-168 (2009).

17) Nakazawa T., Sato A., Mori A., Saito M., Sakamoto K., Nakahara T., Ishii K., Vascular Pharmacol., 49, 77-83 (2008).

18) Nakazawa T., Mori A., Saito M., Sakamoto K., Nakahara T., Ishii K., Naunyn Schmiedebergs Arch. Pharmacol., 376, 423-430 (2008).

19) Nakazawa T., Kaneko Y., Mori A., Saito M., Sakamoto K., Nakahara T., Ishii K., Vascular. Pharmacol., 46, 153-159 (2007).

20) Kaneko Y., Saito M., Mori A., Sakamoto K., Kametaka S., Nakahara T., Ishii K., Biol. Pharm. Bull., 30, 985-989 (2007).

21) Kaneko Y., Saito M., Mori A., Sakamoto K., Nakahara T., Ishii K., J. Ocul. Pharmacol. Ther., 22, 317-322 (2006).

22) Okamura N., Saito M., Mori A., Sakamoto K., Kametaka S., Nakahara T., Ishii K., J. Ocul. Pharmacol. Ther., 23, 207-212 (2007).

23) Moncada S., Palmer R. M., Higgs E. A., Pharmacol. Rev., 43, 109-142 (1991).

24) Koss M. C., Eur. J. Pharmacol., 374, 161-174 (1999).

25) Hardy P., Abran D., Hou X., Lahaie I., Peri K. G., Asselin P., Varma D. R., Chemtob S., Circ. Res., 83, 721-729 (1998).

26) Couttenye M. M., De Clerck N. M., Herman A. G., Brutsaert D. L., J. Cardiovasc. Pharmacol., 7, 971-976 (1985).

27) Chemtob S., Beharry K., Rex J., Chatterjee T., Varma D. R., Aranda J. V., Invest. Opthalmol. Vis. Sci., 32, 1799-1807 (1991).
28) Delaey C., Van De Voorde J., Circ. Res., 83, 714-720 (1998).

29) Delaey C., Van De Voorde J., Opthalmic. Res., 32, 249-256 (2000).

30) Hardy P., Abran D., Li D. Y., Fernandez H., Varma D. R., Chemtob S., Invest. Opthal. Vis. Sci., 35, 580-591 (1994).

31) Hardy P., Beauchamp M., Sennlaub F., Gobeil F. Jr., Tremblay L., Mwaikambo B., Lachapelle P., Chemtob S., Prostaglandins Leukot. Essent. Fat. Acids, 72, 301-325 (2005).

32) Coleman R. A., Smith W. L., Narumiya S., Pharmacol. Rev., 46, 205-229 (1994).

33) Narumiya S., Sugimoto Y., Ushikubi F., Physiol. Rev., 79, 1193-1226 (1999).

34) Sugimoto Y., Narumiya S., J. Biol. Chem., 282, 11613-11617 (2007).

35) Mori A., Nakahara T., Sakamoto K., Ishii K., Naunyn Schmiedebergs Arch. Pharmacol., 384, 603-608 (2011).

36) Mori A., Hanada M., Sakamoto K., Nahkahara T., Ishii K., Eur. J. Pharmacol., 673, 6569 (2011).

37) Mori A., Miwa T., Sakamoto K., Nakahara T., Ishii K., Naunyn Schmiedebergs Arch. Pharmacol., 382, 119-126 (2010).

38) Lam T. T., Abler A. S., Kwong J. M., Tso M. O., Invest. Ophthalmol. Vis. Sci., 40, 23912397 (1999).

39) Izumi Y., Hammerman S. B., Kirby C. O., Benz A. M., Olney J. W., Zorumski C. F., Vis. Neurosci., 20, 97-107 (2003).

40) Bai N., Aida T., Yanagisawa M., Katou S., Sakimura K., Mishina M., Tanaka K., Mol. Brain, 6, 34 (2013).

41) Sucher N. J., Lipton S. A., Dreyer E. B., Vision Res., 37, 3483-3493 (1997).

42) Kwong J. M., Lam T. T., Exp. Eye Res., 71, 437-444 (2000).

43) Moore P., El-sherbeny A., Roon P., Schoenlein P. V., Ganapathy V., Smith S. B., Exp. Eye Res., 73, 45-57 (2001).

44) Qu J., Wang D., Grosskreutz C. L., Exp. Eye Res., 91, 48-53 (2010).

45) Mori A., Ishii T., Kuroki T., Shigeta N., Sakamoto K., Nakahara T., Ishii K., Eur. J. Pharmacol., 616, 64-67 (2009).

46) Oikawa F., Nakahara T., Akanuma K., Ueda 
K., Mori A., Sakamoto K., Ishii K., Naunyn

1081 (2012).

Schmiedebergs Arch. Pharmacol., 385, 1077- 